\section{Genetic effects and potential parents in cowpea}

\section{Francisco Tiago Cunha Dias ${ }^{1}$, Cândida Hermínia Campos de Magalhães Bertini ${ }^{1 *}$ and Francisco Rodrigues Freire Filho ${ }^{2}$}

\begin{abstract}
Six cowpea genotypes and their $F_{2}$ hybrid combinations were evaluated for general and specific combining ability. The Griffing's diallel cross design, Method 2, and mixed model $B$ were used. The genotypes and hybrids differed statistically $(p<0.01)$ for the 10 studied traits. With regard to the general and specific combining ability, there were statistical differences at 1\% probability for all traits. The presence of additive and non-additive gene effects paves the way for breeding new hybrid cultivars. However, additive gene effects were predominant in the trait expression. Genotypes CE-542, CE-954 and CE-796 were identified as the most promising of the test group for inclusion in cowpea breeding programs.
\end{abstract}

Key words: Vigna unguiculata, combining ability, diallel analysis, yield components.

\section{INTRODUCTION}

Cowpea is one of the key food sources in the arid, semi-arid and tropical parts of Asia, Oceania, southern Europe, Africa, southern United States, and Central and South America (Singh et al. 2002). The variations in crop production under different environmental conditions stimulated the development of stable cultivars in breeding programs, with the selection of high-yielding lines (Romanus et al. 2008).

According to FAO (http://faostat3.fao.org/home/index.html), the world cowpea production in 2011 was 4.9 million tons, harvested from a cultivated area of more than 10 million hectares, mainly in Nigeria, Niger and Brazil. However, it is noteworthy that in Brazil, the IBGE does not distinguish data of common bean from those of cowpea, unlike several other producing countries. For Singh (2006), cowpea production is relevant in more than 65 countries. However, the lack of information about the crop in Brazil hampers data collection for FAO.

Historically, cowpea production in Brazil was concentrated in the Northeast (1.2 million hectares) and North $(55,800$ hectares). However, the crop area is expanding in the Midwest region, due to the development of cultivars with characteristics that favor mechanical cultivation (Saidi et al. 2010). Despite the expansion of cultivation into other regions of Brazil, cowpea yields in Ceará have been steadily declining, due to numerous factors, e.g., cultivars with low yield potential and cultivation as extensive secondary crop, associated with other crops, mainly maize, cassava and cotton.

One way to increase the species productivity is by the selection of plants in segregating populations obtained by hybridization of superior genotypes.
Crop Breeding and Applied Biotechnology 16: 315-320, 2016 Brazilian Society of Plant Breeding. Printed in Brazil http://dx.doi.org/10.1590/198470332016v16n4a47

d


Sprague and Tatum (1942) proposed the use of diallel crosses to estimate the general and specific combining ability (GCA and SCA, respectively), in order to select superior parents for crosses. The GCA indicates the mean contribution of a parent or clone to hybrid combinations. The SCA is used to detect cases in which certain hybrid combinations perform better or worse than expected, based on the mean performance of the parents. The GCA is associated to genes with mainly additive effects, aside from the additive epistatic $x$ additive effects. In turn, the SCA is basically defined by genes with dominant effects and various types of interactions (Cruz and Regazzi 2004).

Apart from providing important information about the GCA and SCA, the diallel analysis has been used in cowpea to estimate genetic variance and heritability and to detect the presence of maternal effects (Hazra et al. 1994). Therefore, the purpose of this research was to i) estimate the combining ability of early-maturing and upright genotypes and identify the most promising crosses, and ii) identify the dominant gene action in agronomic traits of cowpea.

\section{MATERIAL AND METHODS}

\section{Genotypes and hybrid combinations}

In the experiment, six cowpea genotypes from the genebank of the Universidade Federal do Ceará and the breeding program of Embrapa Meio Norte, Teresina, Pl, were used. For the selection of the parents, the following criteria were used: earliness (cycle shorter than 70 days), upright growth (main and secondary short branches at right to acute angles in relation to the main stem), little or no common ancestry, and assessment of the agronomic value, based on the general appearance of each genotype. The genotypes CE-542, CE-796, CE-945, CE-954, F4RC1 (Plant J), and MNC03-737E-5-10 were selected.

The crosses between genotypes were made in a greenhouse of Embrapa Meio Norte, by two methods:

\section{Methodology A}

a) Collection of pollen from open flowers (pollen donor genotypes) in the morning, wrapping in paper bags and cold storage $\left(4^{\circ} \mathrm{C}\right)$;

b) Emasculation and pollination of developed flowers (maternal genotypes) that opened after 24 hours, or in the late afternoon of the day prior to natural anthesis.

\section{Methodology B}

a) Emasculation of developed flowers (maternal genotypes) prior to natural anthesis the next morning;

b) Collection of pollen from open flowers (pollen donor genotypes) used for pollination of emasculated flowers the day before.

The genotypes were sown in two steps. Four plants per meter of each genotype were sown in one 3-m row (spacing of $0.25 \mathrm{~m}$ between plants and $1.25 \mathrm{~m}$ between rows). The second sowing was carried out one week after the first.

After artificial pollination, the crosses were labeled with the cross code. The symbols used for the establishment of the cross order was recommended by Freire Filho (2005). Crosses were indicated by " $x$ " and mathematical symbols (parentheses, brackets and keys) were used to establish the order of the crosses. The pods from the crosses were harvested separately, as they reached maturity.

\section{Evaluation of hybrid combinations}

The $F_{1}$ progenies were sown in trays with soil as substrate. After the emergence of the first trifoliate leaf, the seedlings were planted in a greenhouse in Acaraú (lat $3^{\circ} 6^{\prime} \mathrm{N}$, long 40 2' W and alt $30 \mathrm{~m}$ asl), Ceará. To prevent the inclusion of selfings that could occur among the hybrids, the pods of each cross were maintained separate. Furthermore, in the $F_{1}$ plants of each plant pod the expression of morphological genetic markers was separately observed, e.g., for flower color, pod position, shape of the central leaflet, plant pigmentation, and growth habit. Thus, plants on which the markers could not be found were eliminated. 
The $\mathrm{F}_{2}$ generation was evaluated in a randomized complete block design with six replications. Each plot consisted of four $4.0 \mathrm{~m}$ rows, and with rows spaced $0.50 \mathrm{~m}$ and plants $0.20 \mathrm{~m}$ apart, corresponding to an area of $8 \mathrm{~m}^{2}$. The two central rows, disregarding two plant spots on either end, were the evaluated portion $\left(3.6 \mathrm{~m}^{2}\right)$. The traits evaluated in this experiment were days to flowering (DuF), insertion angle of the lateral branches (IALB), number of nodes on the main branch (NNMB), number of pods per plant (NPP), number of seeds per pod (NSP), pod length (PL), 100-seed weight (W100S), grain index (GI), grain yield (GY) in $\mathrm{kg} \mathrm{ha}^{-1}$, and days to maturity (DuM).

In the diallel analysis, we used the parents and $F_{2}$ progenies without reciprocal crosses. The diallel analysis was performed in the $F_{2}$ generation, since is rather difficult to obtain large amounts of $F_{1}$ seeds of cowpea and other pollinated plants. It is also interesting that in the $F_{2}$ generation, the contribution of dominance effects to the mean and variance was reduced to half and to a quarter, respectively, in comparison with the $F_{1}$ generation. Thus, the SCA in the $F_{2}$ generation is not estimated completely. However, the GCA is more accurately estimated because it depends mainly on the additive effects, which is particularly interesting for breeders of autogamous species.

This study was adopted for the analysis method 2 and the mixed model B of Griffing (1965). In this model, the effects of treatments are fixed and those of blocks and experimental error are random. The treatment effects being fixed means that any conclusions are only valid for the experimental material.

The chosen model enables the partitioning of the combinatorial sum of the partial diallels that include the parental genotypes. In this sense, the combining ability of parents can be compared when they are used as control. Moreover, the best hybrid combinations can be identified. All genetic statistical analyses were performed with software Genes (Cruz 2006).

\section{RESULTS AND DISCUSSION}

There were significant differences for all studied traits (Table 1). This presupposes genetic differences between cultivars in diallel crosses. This result is important with regard to the possibility of genetic gains in breeding. For Ramalho et al. (1993), the possibility of selection of superior genotypes depends strictly on the existing genetic diversity in the set of lines, which in turn is a function of the influence of the additive variance. For Krause et al. (2012), the existence of genetic variability in the cultivars used as progenitors is essential for the selection of promising genotypes.

In relation to GCA and SCA (Table 2), statistical differences were observed at $1 \%$ probability for all analyzed trait. These differences indicate variability, resulting from additive and non-additive gene effects, indicating the possibility of obtaining new cultivars or hybrid (Silva et al. 2004). Similar results were reported in cowpea by Carvalho et al. (2012), for the traits 100-seed weight, number of seeds per pod and yield; and by Kimani and Derera (2009) for the traits flowering, number of seeds per pod and 100-seed weight in common bean, indicating the possibility of gains with selection.

According to Medici et al. (2004), significant GCC effects indicate that at least one of the parental genotypes differs from the other in relation to the number of favorable genes with additive effects. A significant SCA indicates that the

Table 1. Estimates of mean squares, general (GCA) and specific (SCA) combining ability for 10 traits of cowpea genotypes in a 6 x 6 diallel analysis

\begin{tabular}{|c|c|c|c|c|c|c|c|c|c|c|c|}
\hline \multirow{2}{*}{$\begin{array}{l}\text { Sources of } \\
\text { Variation }\end{array}$} & \multirow{2}{*}{ df } & \multicolumn{10}{|c|}{ Mean squares } \\
\hline & & $\mathbf{G Y}^{1}$ & NPP $^{2}$ & $\mathrm{NSP}^{3}$ & $\mathrm{PL}^{4}$ & W100S ${ }^{5}$ & DuF $^{6}$ & IALB $^{7}$ & NNMB $^{8}$ & DuM $^{9}$ & $\mathbf{G l}^{10}$ \\
\hline Genotypes & 20 & 79940.598* & $69.00 * *$ & $44.72 * *$ & $53.47^{* *}$ & $72.45 * *$ & $107.90 * *$ & $344.18^{* *}$ & $48.07^{* *}$ & $140.98^{* *}$ & $0.014 * *$ \\
\hline GCA & 5 & $98797.24 *$ & $90.65^{* *}$ & $104.35^{* *}$ & $46.62^{* *}$ & $46.57 * *$ & $29.80 * *$ & $482.03 * *$ & $131.06 * *$ & $192.95^{* *}$ & $0.027 * *$ \\
\hline SCA & 15 & 73655.04* & $61.78^{* *}$ & $24.84 * *$ & $55.76 * *$ & $81.08^{* *}$ & $123.87^{* *}$ & $298.23 * *$ & $20.41 * *$ & $123.65^{* *}$ & $0.010 * *$ \\
\hline Error & 100 & 44301.04 & 5.37 & 2.52 & 2.44 & 3.14 & 1.08 & 27.96 & 0.92 & 0.61 & 0.000741 \\
\hline Means & & 1187.51 & 13.79 & 12.01 & 17.58 & 15.19 & 36.06 & 34.84 & 9.35 & 65.38 & 0.78 \\
\hline GCA & & 4892.33 & 9.40 & 3.72 & 8.88 & 12.98 & 22.14 & 45.04 & 3.24 & 20.50 & 0.001569 \\
\hline SCA & & 1135.33 & 1.77 & 2.12 & 0.92 & 0.90 & 0.59 & 9.45 & 2.71 & 4.00 & 0.000567 \\
\hline
\end{tabular}

${ }^{1}$ Grain yield $\left(\mathrm{kg} \mathrm{ha}^{-1}\right) ;{ }^{2}$ Number of pods per plant; ${ }^{3}$ Number of seeds per pod; ${ }^{4}$ Pod length; ${ }^{5} 100$-seed weight; ${ }^{6}$ Days until flowering; ${ }^{7}$ Insertion angle of the lateral branches; ${ }^{8}$ Number of nodes on the main branch; ${ }^{9}$ Days until maturity; ${ }^{10}$ Grain index. CVe: Coefficient of experimental variation. 
hybrids have a higher or lower performance than expected, based on the GCA of the parents (Oliboni et al. 2013).

It was observed that the mean square effects of GCA and SCA were similar for all study traits (Table 1). However, according to Barelli et al. (2000), inferences based on mean squares are not recommended in autogamous plants, for not detecting the predominance of additive and non-additive gene action. Thus, the use of mean square effects for the genetic quadratic components for GCA and SCA is more appropriate and the assessment of the gene action involved in the trait expression. In this sense, predominant additive gene action was observed for most traits (Table 3 ). This is probably due to the fact that this analysis was conducted in the $F_{2}$ generation, where the additive gene action increases and the dominance deviations decrease.

The estimated GCA effects $\left(g_{j}\right)$ inform about the potential of a genotype to generate good populations for breeding and about the concentration of alleles with predominantly additive effects. The higher the positive or negative $g_{i}$

Table 2. Estimates of the general combining ability (GCA) of six cowpea parents with upright growth and early cycle

\begin{tabular}{|c|c|c|c|c|c|c|c|c|c|c|}
\hline \multirow{2}{*}{ Parents } & \multicolumn{10}{|c|}{ Traits $^{1}$} \\
\hline & GY & NPP & NSP & PL & W100S & DuF & IALB & NNMB & DuM & GI \\
\hline CE-542 (1) & 43.1533 & -2.3104 & 1.5441 & 1.3604 & -1.1691 & -1.5750 & -4.9058 & 2.8466 & 2.7091 & -0.0329 \\
\hline CE-796 (2) & 13.8883 & -0.6404 & 2.0091 & 0.3191 & 1.1595 & 0.0275 & -2.9395 & 1.1429 & -1.4795 & 0.0020 \\
\hline CE-945 (3) & 29.7133 & 0.4170 & -0.6970 & 0.2866 & 0.6545 & 0.4875 & 2.0954 & -1.2995 & 0.9379 & -0.0066 \\
\hline CE-954 (4) & 84.2129 & 0.1308 & -0.0545 & -1.0595 & -1.0616 & 0.2762 & 1.1666 & -0.6595 & -2.9995 & -0.0016 \\
\hline F4RC1 (5) & 10.0945 & 0.6458 & -1.2670 & -1.2558 & -0.2904 & 0.4225 & 3.0816 & -0.8458 & -0.0008 & 0.0420 \\
\hline$S D\left(g_{j}-g_{j}\right)$ & 42.9636 & 0.4731 & 0.3242 & 0.3193 & 0.3619 & 0.2122 & 1.0794 & 0.1965 & 0.1595 & 0.0055 \\
\hline
\end{tabular}

${ }^{1}$ See abbreviations in Table 1.

Table 3. Estimates of the specific combining ability (SCA) of six cowpea parents with upright growth and early cycle

\begin{tabular}{|c|c|c|c|c|c|c|c|c|c|c|}
\hline \multirow{2}{*}{$\begin{array}{l}\text { Parents/ } \\
\text { Hybrids }\end{array}$} & \multicolumn{10}{|c|}{ Estimates of the specific combining ability (SCA) } \\
\hline & GY $^{1}$ & NPP & NSP & PL & W100S & DuF & IALB & NNMB & DuM & GI \\
\hline $1 \times 1$ & -56.09 & 3.94 & -3.36 & -3.80 & -2.33 & -10.24 & 10.86 & -0.23 & -1.62 & 0.01 \\
\hline $1 \times 2$ & 63.46 & -1.17 & 1.21 & 0.18 & -1.58 & -1.01 & 2.67 & 0.90 & 3.05 & -0.02 \\
\hline $1 \times 3$ & -29.47 & 0.67 & 1.74 & 2.52 & 2.92 & 6.19 & -1.83 & -2.01 & -4.85 & -0.01 \\
\hline $1 \times 4$ & 146.38 & -1.61 & 3.84 & 1.93 & 0.26 & 5.90 & -1.91 & 3.81 & 4.73 & -0.02 \\
\hline $1 \times 5$ & -123.08 & -3.10 & -1.42 & 0.17 & 0.64 & 5.25 & -12.54 & -0.41 & -0.58 & 0.01 \\
\hline $2 \times 3$ & 6.62 & 4.10 & 0.39 & -3.61 & -5.92 & 0.92 & 3.17 & -1.94 & -6.16 & -0.02 \\
\hline $2 \times 4$ & -18.76 & 4.81 & -1.21 & -1.95 & -5.38 & -0.86 & -4.62 & -1.77 & -3.57 & 0.04 \\
\hline $2 \times 5$ & -45.81 & -3.41 & 1.51 & 2.30 & -1.73 & -4.51 & -4.65 & -2.04 & -6.57 & -0.07 \\
\hline $2 \times 6$ & 25.59 & -1.00 & 1.08 & 6.97 & 6.01 & -4.28 & -0.21 & -1.23 & 4.43 & -0.01 \\
\hline $3 \times 3$ & 18.29 & -1.28 & 1.36 & 0.53 & -1.64 & -3.36 & -0.28 & 1.10 & 2.74 & -0.02 \\
\hline $4 \times 4$ & 8.91 & 2.90 & 0.69 & 0.70 & 0.58 & 0.21 & 8.29 & -0.97 & 1.78 & 0.01 \\
\hline $4 \times 5$ & -113.27 & -1.62 & -1.40 & 0.95 & 1.81 & -2.43 & -6.83 & -0.23 & -6.21 & -0.02 \\
\hline $4 \times 6$ & 17.72 & -4.08 & 0.73 & -4.38 & -0.07 & -4.37 & -1.94 & 0.51 & 0.78 & 0.02 \\
\hline $5 \times 5$ & 80.73 & 1.65 & 1.15 & -1.01 & -2.25 & 0.59 & 13.41 & 0.75 & 4.12 & 0.02 \\
\hline $5 \times 6$ & 18.61 & 3.74 & -0.09 & -1.20 & 1.26 & 1.98 & 0.29 & 0.01 & 2.61 & -0.01 \\
\hline $6 \times 6$ & -230.45 & 2.01 & -1.23 & -1.18 & -5.58 & 1.38 & 3.18 & 0.79 & -5.54 & -0.04 \\
\hline $\mathrm{SD}\left(\mathrm{S}_{\mathrm{ij}}-\mathrm{S}_{\mathrm{ik}}\right)$ & 113.67 & 1.25 & 0.85 & 0.84 & 0.95 & 0.56 & 2.85 & 0.51 & 0.42 & 0.01 \\
\hline $\mathrm{SD}\left(\mathrm{S}_{\mathrm{ij}}-\mathrm{S}_{\mathrm{kl}}\right)$ & 105.23 & 1.15 & 0.79 & 0.78 & 0.88 & 0.51 & 2.64 & 0.48 & 0.39 & 0.01 \\
\hline
\end{tabular}

${ }^{1}$ See abbreviations in Table 1. 
estimates, the greater is the superiority or not of the parent compared to the other genotypes in the diallel. On the other hand, values close to zero indicate that the performance does not differ from that of the general mean of the crosses (Bastos et al. 2003).

The GCA values of genotype CE-542 were high and positive for yield, NSP and PL and negative for the variables DuF and IRLA (Table 2). This indicates the possibility of using this parent to establish a base population to breed more productive progenies with more seeds, longer pods and more upright plants (negative $g_{i}$ values).

The genotype that contributed most to earliness was CE-954 which, concomitantly, increased yield most (Table 2). Another genotype that can potentially reduce the plant and improve other studied traits was CE-796. Based on this information and the focus of the cowpea breeding program to obtain more productive, upright and early genotypes, crosses between the genotypes CE-542 and CE-954 and CE-796 were identified as the most promising to obtain gains for these traits.

The effect of SCA is interpreted as the deviation of a hybrid from what would be expected based on the GCA of its parents. It is therefore worth highlighting the importance of non-additive interactions resulting from genetic complementation between the parents. Thus, the study of SCA allows predict the possibility of genetic gain by the exploitation of heterosis (Bastos et al. 2003).

High positive or negative SCA $\left(\mathrm{S}_{\mathrm{ij}}\right)$ estimates show that the performance of a cross is relatively better or worse than would be expected based on the GCA of the parents (Rainey and Griffiths 2005). Therefore, hybrid combinations with high means are expected when at least one parent has a more favorable effect of GCA (Tchiagam et al. 2011). Thus, the most promising crosses for higher yield were CE-542 x CE-954 and CE-542 x CE-796 (Table 3). The reason is that these combinations resulted in good yields and high SCA estimates, as were the genotypes with more favorable effects for GCA.

With regard to plant architecture, the insertion angle of lateral branches decreased most in cross CE-542 x F4RC1, probably because it involved more upright plants. For a short crop cycle, the cross with greatest reduction was CE-954 $x$ F4RC1.

\section{ACKNOWLEDGEMENTS}

The authors thank Brazilian Federal Agency for Support and Evaluation of Graduate Education (CAPES) for funding this project and the Federal University of Ceará and Embrapa Meia Norte for their help in carrying out the research.

\section{REFERENCES}

Barelli MAA, Gonçalves-Vidigal MC, Amaral Júnior AT, Vidigal Filho PS, Scapim CA and Sagrilo E (2000) Diallel analysis for grain yield and yield components in Phaseolus vulgaris L. Acta Scientiarum. Agronomy 22: 883-887.

Bastos IT, Barbosa MHP, Cruz CD, Burnquist WL, Bressiani JA and Silva FL (2003) Análise dialélica em clones de cana-de-açúcar. Bragantia 62: 199-206.

Carvalho LCB, Silva KJD, Rocha MM, Sousa MB, Pires CJ and Nunes JAR (2012) Phenotypic correlations between combining abilities of $F_{2}$ cowpea populations. Crop Breeding and Applied Biotechnology 12: 211-214.

Cruz CD (2006) Programa Genes. $1^{\text {st }}$ edn, Editora UFV, Viçosa, 382p.

Cruz CD and Regazzi AJ (2004) Modelos biométricos aplicados ao melhoramento genético. Editora UFV, Viçosa, 390p.

Freire Filho FR, Ribeiro VQ, Barreto PD and Santos AA (2005) melhoramento genético. In Freire Filho FR, Lima JAA and Ribeiro VQ (eds) Feijão-caupi: avanços tecnológicos. Embrapa Informação
Tecnológica, Brasília, p. 29-92.

Griffing BAA (1956) Concept of general and specific combining ability in relation to diallel crossing systems. Australian Journal of Biological Sciences 9: 463-493.

Hazra P, Das PK and Som MG (1994) Analysis of heterosis for pod yield and its components in relation to genetic divergence of the parents and specific combining ability of the crosses in cowpea (Vigna unguiculata (L.) Walp). Jornal Genetic Plant Breeding 53: 418-423.

Kimani J and Derera J (2009) Combining ability analysis across environments for some traits in dry bean (Phaseolus vulgaris L.) under low and high soil phosphorus conditions. Euphytica 166: 1-13.

Krause w, Souza RS, Neves LG, Carvalho MLS, Viana AP and Faleiro FG (2012) Ganho de seleção no melhoramento genético intrapopulacional do maracujazeiro-amarelo. Pesquisa Agropecuária Brasileira 47: 51-57.

Medici LO, Pereira MB, Lea PJ and Azevedo RA (2004) Diallel analysis of maize lines with contrasting responses to applied nitrogen. Journal of Agricultural Science 142: 535-541.

Oliboni R, Faria MV, Neumann M, Resende JTV, Battistelli GM, Tegoni RF 


\section{FTC Dias et al.}

and Oliboni DF (2013) Análise dialélica na avaliação do potencial de híbridos de milho para a geração de populações-base para obtenção de linhagens. Agronomia 34: 7-18.

Rainey KM and Griffiths PD (2005) Diallel analysis of yield components of snap beans exposed to two temperature stress environments. Euphytica 142: 43-53.

Ramalho MAP, Santos JB and Zimmermann MJO (1993) Genética quantitativa em plantas autógamas: aplicação ao melhoramento do feijoeiro. Editora UFG, Goiânia, 271p.

Romanus KG, Hussein S and Mashela WP (2008) Combining ability analysis and association of yield and yield components among selected cowpea lines. Euphytica 162: 205-210.

Saidi M, Itulya FM, Aguyoh J and Ngouajio M (2010) Leaf harvesting time and frequency affect vegetative and grain yield of cowpea. American Journal 102: 827-833.

Scott AJ and Knott M (1974) Cluster analysis method for grouping means in the analysis of variance. Biometrics 30: 507-512.
Silva MP, Amaral Junior AT, Rodrigues R, Daher RF, Leal NR and Schuelter AR (2004) Análise dialélica da capacidade combinatória em feijãode-vagem. Horticultura Brasileira 22: 277-280.

Singh BB, Ehlers JD, Sharma B and Freire Filho FR (2002) Recent progress in cowpea breeding. In Fatokun CA, Tarawali SA, Singh BB, Kormawa $P M$ and Tamò $M$ (eds) Challenges and opportunities for enhancing sustainable cowpea production. International Institute of Tropical Agriculture, Ibadan, p. 4-8.

Singh BB (2006) Cowpea breeding at IITA: Highlights of advances impacts. In Anais do congresso nacional de feijão-caupi. Embrapa Meio-Norte, Teresina, p. 1-4.

Sprague GF and Tatum LA (1942) General versus specific combining ability in single crosses of corn. Journal of the American Society of Agronomy 34: 923-932.

Tchiagam JN, Bell JM, Nassourou AM, Njintang NY and Youmbi E (2011) Genetic analysis of seed proteins contents in cowpea (Vigna unguiculata L. Walp.). African Journal of Biotechnology 10: 30773086 . 